\title{
Relato de caso raro de corpo estranho em vértebra lombar
}

\author{
Report of a rare case of foreign body in a lumbar vertebra
}

\author{
Helton Luiz Antonio Defino ${ }^{1}$ \& Antônio Carlos Shimano ${ }^{2}$
}

\section{RESUMO}

É apresentado caso raro de corpo estranho (pedaço de tecido de confecção) no interior do corpo de L5, cujos sintomas estavam relacionados à compressão da quinta raiz lombar esquerda

O quadro clínico e radiológico são apresentados, destacando a raridade da lesão observada, o tratamento realizado e o seu resultado após 3 anos de seguimento.

Descritores: Coluna vertebral; Infecção vertebral

\section{INTRODUÇÃO}

Na prática diária nos deparamos às vezes com situações resultantes de uma constelação de acontecimentos que culminam com um determinado tipo de lesão, a qual seria impossível de imaginarmos nas situações que envolvem os traumatismos cotidianos, e cuja probabilidade de ocorrência aproximaria-se de cifras muito reduzidas. O caso clínico que relataremos é um bom exemplo, e com muita certeza não será possível relatar um segundo até o final de nosso exercício profissional. A sua raridade e fatores associados ao seu acontecimento nos motivaram a relata-lo.

O paciente era do sexo masculino, trabalhava na construção civil e contava com 62 anos de idade no momento da nossa avaliação. Sua queixa principal era dor na região lombar com irradiação para o membro inferior esquerdo, no dermátomo correspondente à raiz de L5 . O paciente referia que a dor tornavase mais intensa com os movimentos e melhorava com o repouso na posição de Fowley. Referia que a dor havia iniciado aproximadamente há 1 mês após sofrer queda de um andaime de construção. O paciente referia que durante a queda havia sofrido ferimento perfurante na nádega, e que o ferimento ainda

\section{SUMMARY}

A rare case of foreign body (a piece of cloth tissue) found in the body of $L 5$, presenting symptoms related to compression of the fifth left lumbar root is presented.

Clinical and radiological picture, with emphasis on rarity of the lesion, the treatment performed and its result after 3-year follow-up are discussed.

Key Words: Lumbar spine; vertebral infection

\section{INTRODUCTION}

In daily practice a doctor sometimes can face situations resulting form a range of incidents leading to injuries one would never wonder that could come from daily life accidents and a that are very unlikely to happen. The clinical case we report here is an example of this, and it is very much likely we will not be able to report another similar case to the end of our professional life. The rarity of this case and the findings linked to it motivated us to report it.

The patient was a 62 years old male who worked in building construction, who presented with a complaint of lumbar pain irradiated to the $L 5$ dermatome. The pain worsened with movements and improved at rest in Fowley's position. Symptoms started approximately one month after a fall from a scaffolding of construction. He reported that during the fall had an perforating wound at his buttocks and that the wound was still open and draining secretion even though several surgical cleanings were performed.

At physical examination it was found a punctiform wound at left buttocks draining sero-purulent secretion. Lumbar spine had straightened lordosis, and all lumbar spine movements were painfully limited.
Trabalho realizado com auxílio do CNPq

Agradecimento - Os autores agradecem a BAUMER pela confecção dos implantes utilizados nos ensaios mecânicos.

1 Professor Associado do Departamento de Cirurgia, Ortopedia e Traumatologia da Faculdade de Medicina de Ribeirão Preto- USP

2 Engenheiro Mecânico do Laboratório de Bioengenharia da Faculdade de Medicina

de Ribeirão Preto- USP - E.Mail.: hladefin@fmrp.usp.br

Trabalho recebido em 25/05/2000. Aprovado em 15/12/2000
This work had partial support of CNPq.

Acknowledgements: - The authors acknowledge BAUMER for making the implants used in mechanical assays.

1 Associate Professor of Departamento de Cirurgia, Ortopedia e Traumatologia da Faculdade de Medicina de Ribeirão Preto- USP

2 Mechanical Engineer of the Bioengineering Lab of Faculdade de Medicina de Ribeirão Preto- USP 


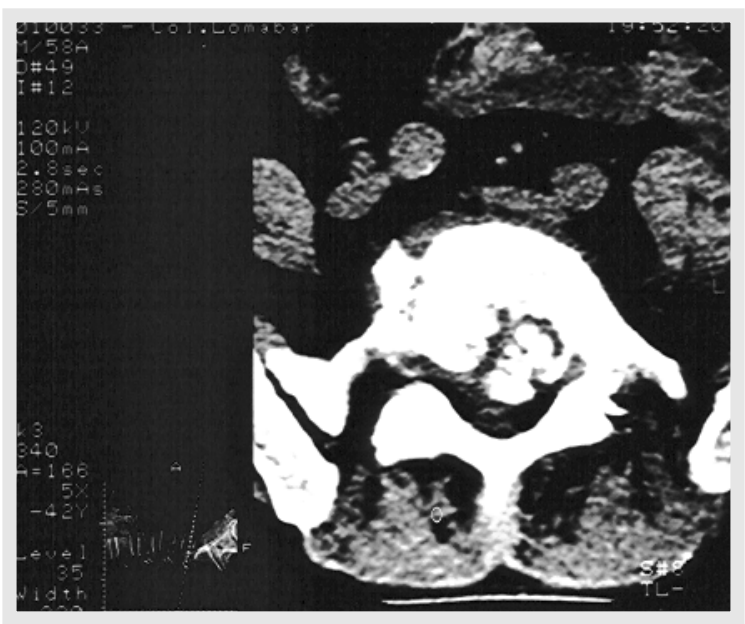

Figura 1 - Corte tomográfico ao nível de L5. Observar a lesão do corpo da vértebra e material circunscrito que invade o canal vertebral.

Figure 1 - CT scan at L5. See the lesion of the vertebral body and the circumscribed material invading the vertebral canal.

encontrava-se aberto e com saída de secreção, apesar de ter sido realizado vários desbridamentos cirúrgicos.

Ao exame físico observava-se um ferimento puntiforme na nádega esquerda, com saída de secreção sero-purulenta. A coluna lombar apresentava retificação da lordose e todos os movimentos da coluna lombar apresentavam limitação dolorosa.

O exame neurológico era compatível com o comprometimento da raiz de L5 a esquerda, expressado pela diminuição da força de extensão do halux, diminuição da sensibilidade na face lateral da perna esquerda,e o teste de elevação do membro inferior esquerdo era positivo.

Os exames de imagem mostravam lesão ao nível da quinta vértebra lombar, cujo corpo apresentava material circunscrito e irregular, bem delimitado em relação ao corpo da vértebra, e que invadia parcialmente o canal vertebral. (Figura 1) O corpo de S1 e o corpo de L4 também apresentavam área de lesão em todos os cortes tomográficos. (Figura 2)

Após a análise do quadro clínico e dos exames complementares, entendiamos que estava ocorrendo uma compressão da raiz de L5 à esquerda, associada a um processo patológico da quinta vértebra lombar. Havia dúvida sobre a etiologia da lesão do corpo de L5 e também com relação ao seu período de aparecimento (haveria alguma lesão prévia no momento da queda, ou a mesma teria ocorrido após a queda?).

O paciente foi submetido à cirurgia para descompressão da raiz de $L 5$ e biópsia do corpo de L5. Durante a exposição da raiz de L5 foi observado que a raiz encontrava-se hiperemiada, e a biópsia do corpo de L5 foi realizada pela mesma abordagem utilizada para a descompressão da raiz nervosa, tendo sido retirado um fragmento da parede posterior do corpo vertebral de
Neurological examination was compatible to left $L 5$ root commitment as expressed by decrease in strength of hallex extension, sensation decrease in the lateral aspect of left leg, and positive elevation of the left lower limb test.

Imagery tests demonstrated an injury in fifth lumbar vertebra, with an irregular and circumscribed material, well limited in relation to the body of the vertebra and partially invading the vertebral canal (Figure 1). S1 and L4 bodies also presented an injury area in all scans (Figure 2).

Analyzing the clinical picture and complementary examinations, we could state that there was a compression of the $L 5$ left root, associated to a pathological process of the fifth lumbar vertebra. There was doubt about the etiology of the process in L5, and also about the time it started (did it exist before the fall or was a result of it?)

The patient underwent surgery for decompression of $L 5$ root and biopsy of $L 5$ body. During the exposure of the root, it was observed that it was hyperemic and biopsy of the $L 5$ body was performed through the same exposure, being removed a fragment of the posterior wall of $L 5$ body, curettage of part of the cancellous bone of the vertebral body. During the removal of cancellous bone we found and removed a very badly smelling fragment of cloth tissue (jeans) inside the vertebral body. At the moment it was not possible to understand the origin of that piece of cloth tissue measuring about $1 \times 3 \mathrm{~cm}$. After a better analysis, it was concluded to be a piece of the tissue of the pants the patient wearied at the moment of the accident (Figure 3).

Starting from this observation and reviewing the imagery examinations, it was possible to understand the mechanism of the injury. During the fall an iron rod that penetrated the buttocks leaded 

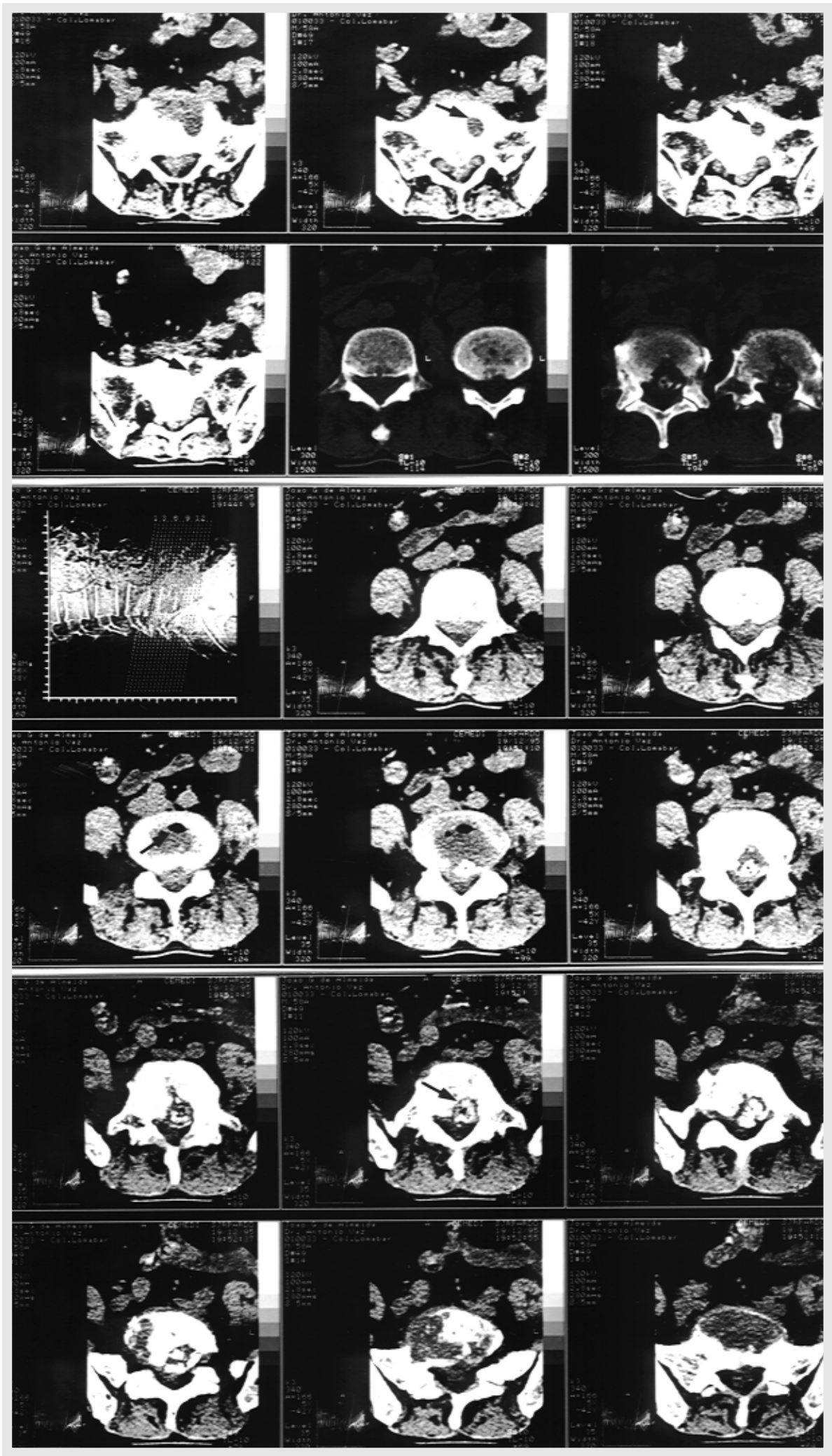

Figura 2 - Cortes tomográficos de L4-L5-S1. Observar as lesões do corpo de L4-L5 e S1 (setas).

Figure 2 - CT scan of L4-L5-S1. See the lesions of the bodies of $L 4-L 5$ and $S 1$ (arrows). 


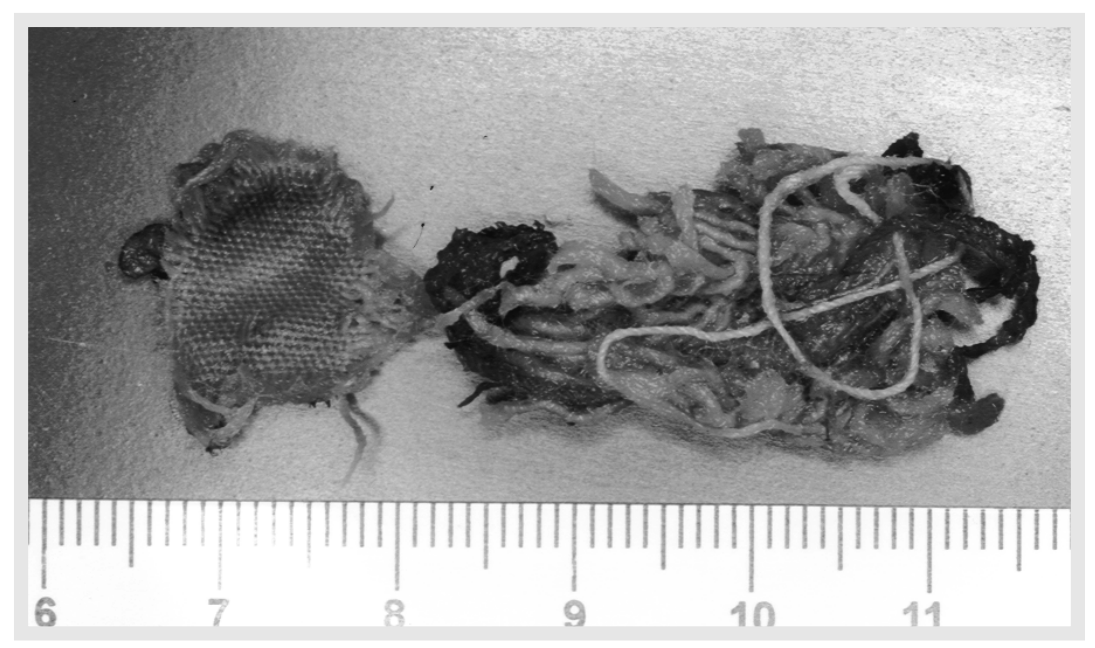

Figura 3 - Pedaço de tecido de confecção (jeans) retirado do interior do corpo de L5.

L5, seguida da curetagem de parte do osso esponjoso do corpo da vértebra. Durante a remoção do osso esponjoso do corpo de L5, nos deparamos com fragmentos de tecido de confecção (jeans) no interior do corpo vertebral, que foram extraídos, exalando um odor fétido durante a sua remoção. No momento não era possível entender a origem daqueles pedaços de tecido de confecção de cerca de $1 \times 3 \mathrm{~cm}$, que após observação mais detalhada conclui-se que correspondiam a fragmentos da calça jeans que o paciente vestia no dia da sua queda. (Figura 3 )

A partir dessa observação, e revendo os exames de imagem, foi possível entender o mecanismo da lesão que o paciente havia sofrido. Durante a queda o pedaço de ferro que penetrara pela nádega, havia levado um pedaço da roupa do paciente até o corpo da vértebra de L5. Esse fragmento de tecido produzira a infecção do corpo da vértebra, que juntamente com o trauma sofrido, havia provocado a sua destruição parcial e compressão

Figura 3 - Fragment of cloth tissue (jeans) removed from the body of $L 5$.

a piece of cloth to the body of L5. This fragment of cloth tissue produced the infection of the vertebral body leading to its partial destruction and partial compression of $L 5$ root. The presence of secretion in the wound could now be understood as well as the difficulty in obtaining healing.

The clinical follow-up demonstrated a good result and at this moment, with a 3 years follow-up, the patient has no symptoms.

\section{DISCUSSION}

This kind of injury here described has some picturesque aspects. An iron rod penetrated his buttocks, reached his sacrum and the fourth lumbar vertebra, leaving a piece of cloth tissue of his pants inside the body of $L 5$. The path of the iron rod was restricted to bone tissue, and, considering how other very close structures were not involved makes this a very rare case.
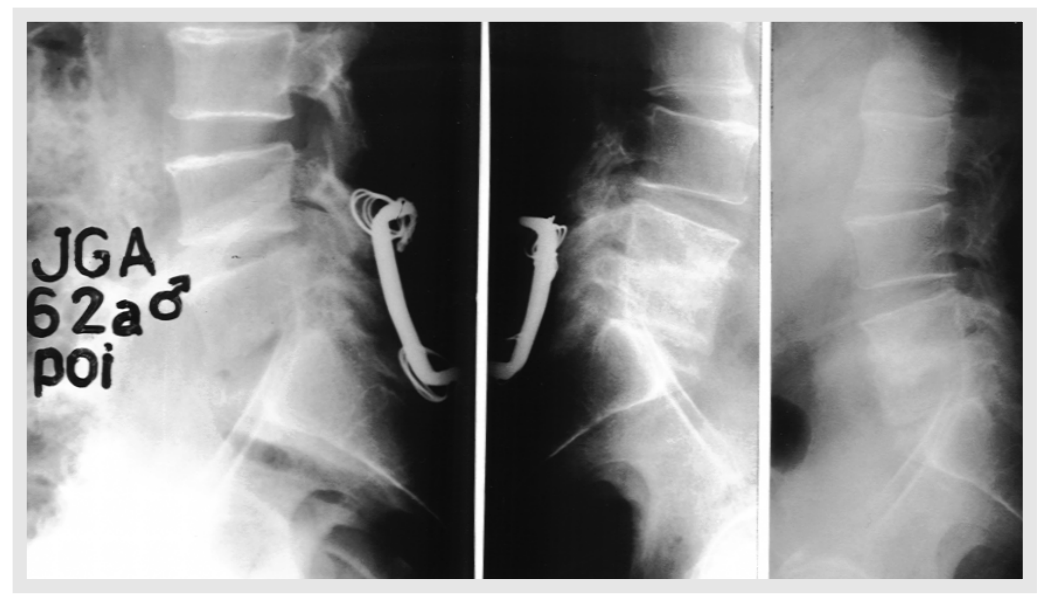

Figura 4 - Radiografias do pós-operatório imediato (A), 1 ano após a cirurgia (B) e após a retirada do material de fixação (C). Observar a anquilose entre L4-L5.

Figura 4 - Radiographies took at immediate post-operative period (A), 1 year after the surgery (B) and after removal of fixation material (C). See the ankylosis between L4-L5. 
da raiz de L5. Desse modo a saída de secreção pelo ferimento podia ser agora entendida, bem como a dificuldade em obter a sua cicatrização com os desbridamentos realizados.

A evolução clínica foi favorável e no momento com 3 anos de seguimento clínico o paciente encontra-se assintomático.

\section{DISCUSSÃO}

O tipo de lesão que descrevemos apresenta aspectos pitorescos da sua ocorrência, pois a haste de ferro penetrou pela nádega do paciente, atingiu o sacro e penetrou até a quarta vértebra lombar, deixando um fragmento de tecido da calça do paciente no interior do corpo da vértebra de L5. O trajeto da haste de ferro ficou restrito somente ao tecido ósseo, e pela proximidade das outras estruturas e órgãos que não foram atingidos, torna-se algo raro.

Por uma questão simplesmente de sorte foi possível a remoção do fragmento da calça do paciente, que permitiu não somente a realização do diagnóstico, mas também a resolução do problema. Com relação à realização da biópsia, a mesma poderia ter sido realizada pelo pedículo vertebral, e com muita probabilidade não teríamos removido o fragmento de tecido. Não conseguimos imaginar qual teria sido a evolução, caso o fragmento de tecido não houvesse sido removido durante a cirurgia que foi realizada.

Na época do atendimento não dispunhamos da ressonância magnética, que certamente teria auxiliado na elucidação do diagnóstico, oferecendo subsídios adicionais.

Com relação ao tratamento realizado, foi feita a fixação de $L 4$ a S1 por meio de retângulo de Hartchild durante a descompressão da raiz e biópsia do corpo da vértebra (Figura 4), pois acreditávamos que seria necessário a limpeza e desbridamento anterior do corpo vertebral, que somente não foi realizado pela falta de condições locais. Temíamos na época a abordagem desse sítio da coluna vertebral, que estava acompanhado de infecção. Talvez hoje, com maior experiência com o tratamento cirúrgico das infecções, nossa abordagem teria sido sem dúvida alguma o desbridamento anterior do corpo de L5, associado a colocação de enxerto córtico esponjoso. O método de fixação utilizado nos dias atuais seria um sistema de fixação vertebral utilizando parafusos pediculares, associado ao desbridamento anterior do corpo vertebral com enxerto de ilíaco. Porém, o resultado alcançado com o método de tratamento realizado foi satisfatório do ponto de vista clínico e radiológico, tendo ocorrido a anquilose do segmento vertebral L4-L5,ainda que com perda da lordose desse segmento da coluna lombar, com remissão total dos sintomas e cicatrização da fístula da nádega. (Figura 4)

O material utilizado na fixação foi removido após 2 anos da realização da cirurgia, devido à presença de saída de secreção pela incisão cirúrgica. O paciente apresentou saída de secreção e fístula na incisão posterior, apesar de ter ocorrido anquilose na parte anterior da coluna.Com a retirada do material de síntese ocorreu a cicatrização da incisão cirúrgica e da fistula, tendo o paciente apresentado boa evolução clínica.
For mere chance it was possible to remove the tissue fragment, what not only allowed the diagnosis but also to solve the problem. Regarding the biopsy, it could have been performed through vertebral pedicle, and very probably we would not have removed the tissue fragment. We can only wonder what would the evolution be if the tissue fragment was not removed during the surgery.

At the time this patient was treated we did not have the availability of MRI, which would certainly help the diagnosis.

Regarding treatment, a fixation from $L 4$ to $S 1$ was performed with a Hartchild rectangle during the decompression of the root and biopsy of the vertebral body (Figure 4), since we believed it would be necessary an anterior surgical approach for cleaning and debridement of the vertebral body, that was not performed due to lack of local conditions. We were then afraid of reaching this infected area. Maybe now, more experienced in surgical treatment of bone infections our choice would certainly be an anterior approach, with a surgical debridement of the vertebral body and cortico-spongeous bone grafting. The method of fixation used nowadays would be with the use of pedicular screws associating the anterior debridement to iliac bone grafting. However the results achieved with the treatment were satisfactory from a clinical and radiological point of view, with an ankylosis of L4-L5 segment even though loosing lordosis of this lumbar spine segment. Symptoms remitted completely, and the buttocks wound heal. (Figure 4)

Fixation material was removed 2 years after the surgery due to secretion through the surgical scar. Secretion and fistula was observed in the posterior scar, even though ankylosis occurred in the anterior part of the spine. Once the fixation material was removed, a complete healing of the surgical wound was observed. 